\title{
INTRINSIC BIOREMEDIATION OF FUEL CONTAMINATION IN GROUND WATER AT A FIELD SITE
}

D.H. Kampbell ${ }^{1}$, T.H. Wiedemeier ${ }^{2}$, and J.E. Hansen ${ }^{3} ;{ }^{1}$ R.S. Kerr Environmental Research Laboratory, Ada, OK 74820; '² Parsons Engineering Science, Inc., Denver, CO 80290; and

${ }^{3}$ U.S. Air Force Center for Environmental Excellence, Brooks Air Force Base, TX 78235

\section{ABSTRACT}

A spill of gasoline occurred at an automobile service station in 1986. Oily phase residue in the subsurface has, for the past eight years, continued to release water soluble fuel hydrocarbons into the aquifer. The site was characterized for implementation of intrinsic remediation. The subsurface was a beach sand with sea shell fragments. The water table was near 1.3 meters below ground surface. Surface dimensions over the plume were about 200 meters downgradient and 60 meters in width. Three points to coincide with direction of ground water flow were selected in the plume for water quality assessments. Both methane and trimethylbenzene were used as surrogate tracers to normalize loss of contaminants. Aerobic respiration and methanogenesis accounted for most biodegradation obtained. Assimilation capacities of dissolved oxygen, ferrous iron, and methane distributions when compared to BTEX concentrations showed that the ground water has sufficient capacity to degrade all dissolved BTEX before the plume moves beyond 250 meters downgradient. Evidence obtained from loss of contaminants, geochemistry and microbial breakdown chemicals showed that intrinsic bioremediation technology would be a viable option to restore the site.

KEY WORDS

intrinsic remediation, BTEX plume, aerobic respiration, methanogenesis

\section{INTRODUCTION}

A detailed characterization study was conducted during March 1994 at a fuel spill location on Patrick Air Force Base in Cocoa Beach, Florida. Core material and ground water samples were collected and analyzed to predict the influence of natural attenuation on dissolved contaminant migration and attenuation. Technical protocol fol- lowed was reported by Wiedemeier et al. [1]. Intrinsic remediation of contaminants in ground water incorporates mechanisms of biodegradation, sorption, dilution, volatilization, dispersion and advection. All of these processes can operate concurrently during field scale implementation of bioremediation technology. The respiration processes microorganisms used to bring about a re-

\begin{tabular}{l|l}
\hline Aerobic respiration & $7.5 \mathrm{O}_{2}+\mathrm{C}_{6} \mathrm{H}_{6}=6 \mathrm{CO}_{2}+3 \mathrm{H}_{2} \mathrm{O}$ \\
Denitrification & $6 \mathrm{NO}_{3}^{-}+6 \mathrm{H}^{+}+\mathrm{C}_{6} \mathrm{H}_{6}=6 \mathrm{CO}_{2}+6 \mathrm{H}_{2} \mathrm{O}+3 \mathrm{~N}_{2}$ \\
Iron reduction & $6 \mathrm{OH}^{+}+3 \mathrm{OFe}(\mathrm{OH})_{3}+\mathrm{C}_{6} \mathrm{H}_{6}=6 \mathrm{CO}_{2}+3 \mathrm{OFe}^{2+}+78 \mathrm{H}_{2} \mathrm{O}$ \\
Sulfate reduction & $7.5 \mathrm{H}^{+}+3.75 \mathrm{SO}_{4}{ }^{2-}+\mathrm{C}_{6} \mathrm{H}_{6}=6 \mathrm{CO}_{2}+3.75 \mathrm{H}_{2} \mathrm{~S}+3 \mathrm{H}_{2} \mathrm{O}$ \\
Methanogenesis & $4.5 \mathrm{H}_{2} \mathrm{O}+\mathrm{C}_{6} \mathrm{H}_{6}=2.25 \mathrm{CO}_{2}+3.75 \mathrm{CH}_{4}$ \\
\hline
\end{tabular}

Table 1. Benzene biodegradation reactions. 


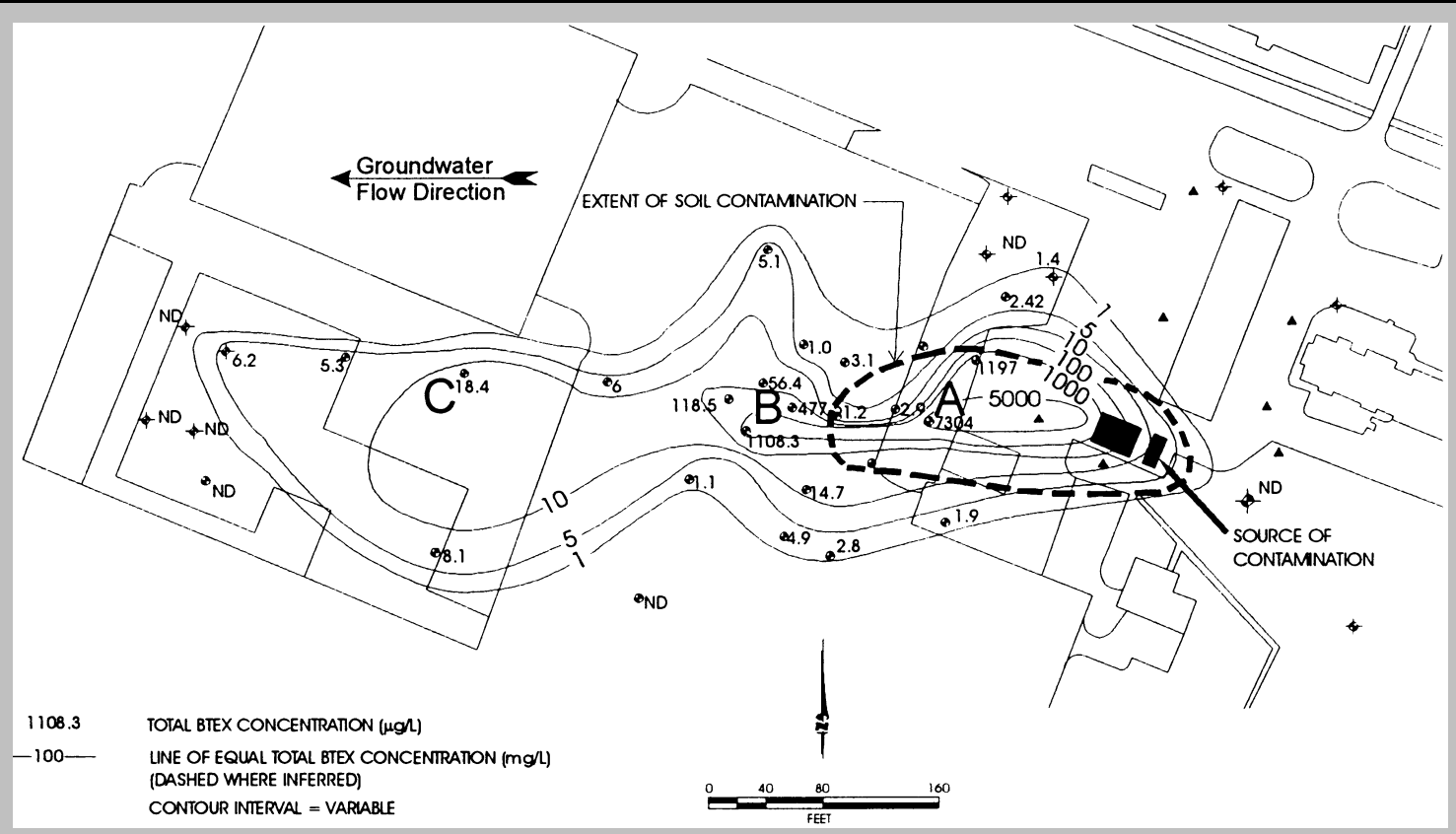

Figure 1. Total BTEX in ground water, Patrick AFB, Florida.

duction in total contaminant mass in ground water are aerobic respiration, denitrification, iron or manganese reduction, sulfate reduction and methanogenesis (Table 1). These processes, called intrinsic bioremediation, are important contributors to benzene, toluene, ethylbenzene and xylenes (BTEX) removal from ground water.

If oily phase residue is present in the subsurface, it can act as a continuing source of contamination. To demonstrate intrinsic bioremediation at field spill sites, the quan- tification of biodegradation of BTEX - which are major fuel constituents-is very important. Patterns and rates can vary from site to site. The loss of contaminants downgradient to our site was used as evidence for the occurrence of intrinsic bioremediation.

\section{SPILL SITE}

About 700 gallons of unleaded gasoline were released into the subsurface in 1986 at an on-base service station location. The subsurface matrix consisted of beach sand

\begin{tabular}{l|ccc}
\hline Compound & Point A & Point B & Point C \\
\hline Benzene & 724 & 960 & 1 \\
Toluene & 737 & 17 & 2 \\
Ethylbenzene & 823 & 12 & 1 \\
Xylenes & 5020 & 120 & 15 \\
Trimethylbenzene & 750 & 28 & 3 \\
Total BTEX + TMB & 8054 & 1137 & 23 \\
Measured methane & 14000 & 8800 & 2140 \\
Methane produced from BTEX \& TMB & 6282 & 887 & 18 \\
\hline
\end{tabular}

Table 2. BTEX concentrations, $\mu \mathrm{g} / \mathrm{L}$. 


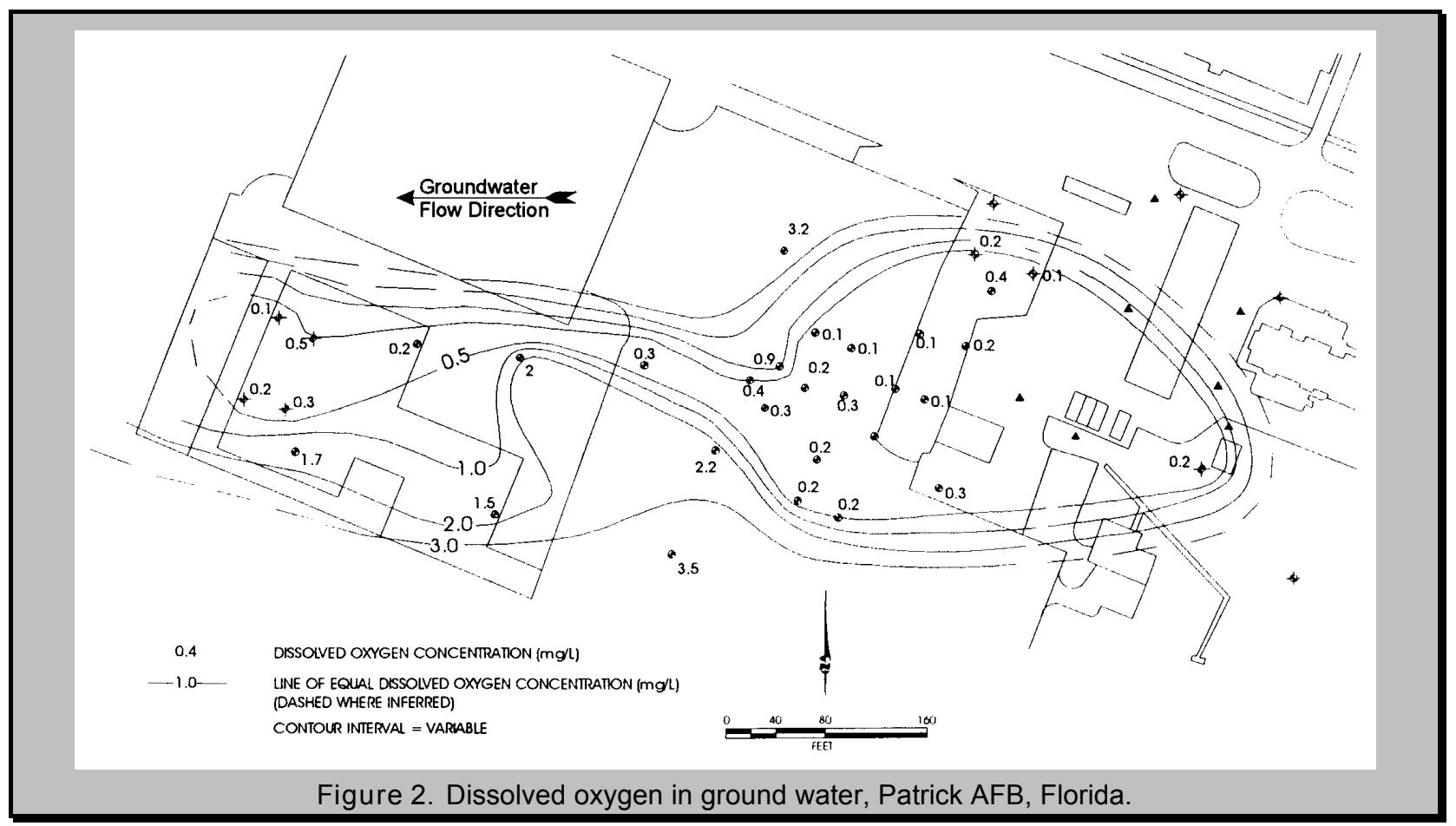

containing sea shell fragments to a depth of about 7.5 meters below ground surface (bgs) where a confining marl formation was located. The water table was near 1.3 meters bgs, and the downward gradient measured in monitoring point wells was $0.002 \mathrm{~m} / \mathrm{m}$. Slug testing indicated that average hydraulic conductivity was near $0.026 \mathrm{~cm} / \mathrm{sec}$. The average advective ground water velocity was about $48 \mathrm{~m} /$ year assuming a sand porosity of 0.35 . Using TOC measurements, a retardation factor of 2.6 was calculated for benzene. The effective solute transport velocity was 18.3 m/year.

\section{RESULTS}

The extent of the plume was measured by the BTEX dissolved in the ground water as shown in Figure 1. Surface area over the plume was about 200 meters long and 60 meters wide. Free-floating gasoline was not detected in any of the sampled wells.

\section{LOSS OF CONTAMINANTS}

Point $A$ as shown in Figure 1 was selected for the highest dissolved BTEX with points $\mathrm{B}$ and $\mathrm{C}$ at 38 and 98 meters, respectively,

\begin{tabular}{l|cccc}
\hline \multicolumn{1}{c|}{ Compound } & $\begin{array}{c}\text { Point B } \\
\text { Corrected } \mu \mathrm{g} / \mathrm{L}\end{array}$ & $\begin{array}{c}\text { Biodegradation } \\
\text { A to B \% }\end{array}$ & $\begin{array}{c}\text { Point C } \\
\text { Corrected } \mu \mathrm{g} / \mathrm{L}\end{array}$ & $\begin{array}{c}\text { Biodegradation } \\
\text { B to C \% }\end{array}$ \\
\hline Benzene & 2008 & 0 & 4 & 100 \\
Toluene & 35 & 95 & 9 & 46 \\
Ethylbenzene & 24 & 97 & 9 & 22 \\
Xylenes & 251 & 95 & 67 & 43 \\
Total BTEX \& TMB & 2400 & 70 & 103 & 91 \\
\hline
\end{tabular}

Table 3. Percent loss using methane-corrected levels. 


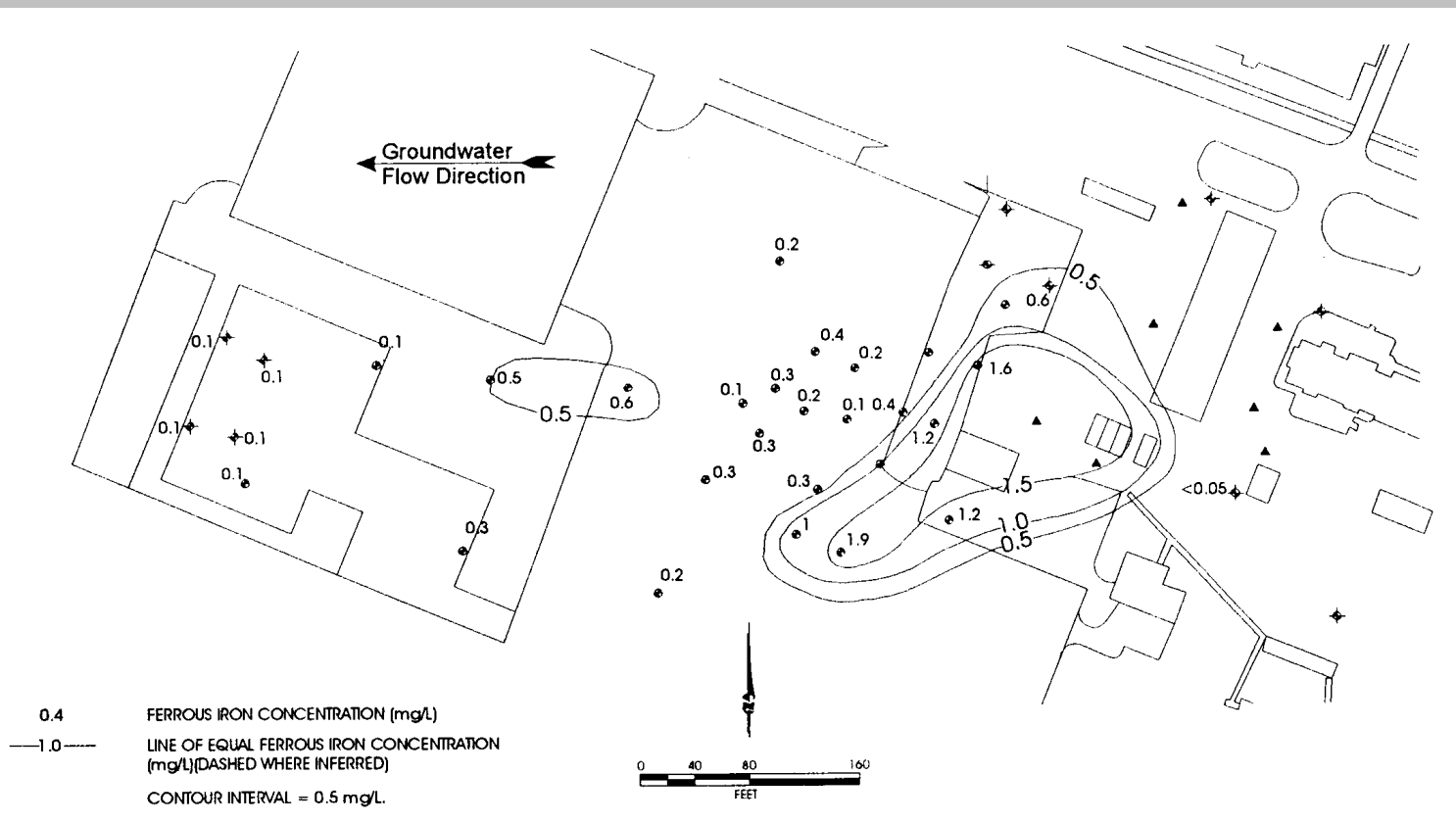

Figure 3. Ferrous iron in ground water, Patrick AFB, Florida.

downgradient in the plume. BTEX concentrations are listed in Table 2. Methane produced from BTEX and TMB = (measured BTEX + TMB) $\times(0.78)$. Ground water isopleth maps for BTEX, dissolved oxygen, ferrous iron and methane are shown in Figures 1, 2, 3 and 4, respectively. Both methane and trimethylbenzene (TMB) were selected as surrogate tracers. It was assumed that all methane was both stable and produced from BTEX components (Table 3). For example, methane at point $A$ as a tracer was $14000+6282=20282 \mu \mathrm{g} / \mathrm{L}$. Our usual approach has been to use trimethylbenzene (TMB) as a recalcitrant compound to correct BTEX concentrations for dispersion, dilution, sorption and volatilization. For some reason benzene was higher at point $B$ than at point $A$, which indicated that TMB was, under these site conditions, not entirely recalcitrant. However, the TMB corrected toluene, ethylbenzene and xylenes decreased 30 to 60 percent between point $A$ and $B$, which confirmed that biodegradation occurred (Table 4). Even though some biodegradation of TMB may have occurred, the corrected values would underestimate the percent
BTEX biodegraded. Between points $B$ and $C$ the relative decrease in TMB had a reduction rate similar to BTEX. Therefore, we chose not to use TMB as a surrogate tracer and concluded that BTEX/TMB ratios did not substantiate that intrinsic bioremediation occurred.

\section{GROUND WATER GEOCHEMISTRY}

The redox potential at the site ranged from 54 to $-293 \mathrm{mV}$. Low redox potential coincided with sampling points of high BTEX contamination, low dissolved oxygen, some ferrous iron, and elevated methane concentrations. Water temperature was a warm $26^{\circ} \mathrm{C}$, which suggested that bacterial growth rates could be high. Total alkalinity ranged from 148 to $520 \mathrm{mg} / \mathrm{L}$, which would suffice to buffer $\mathrm{pH}$ changes caused by BTEX biooxidation reactions. pHs near 7 were in the optimal range of BTEXdegrading microbes. Nitrate was very low so denitrification for BTEX removal was not viable. Sulfate at levels up to $86 \mathrm{mg} / \mathrm{L}$ were fairly high, but a relationship between sulfate and BTEX changes was not apparent. 


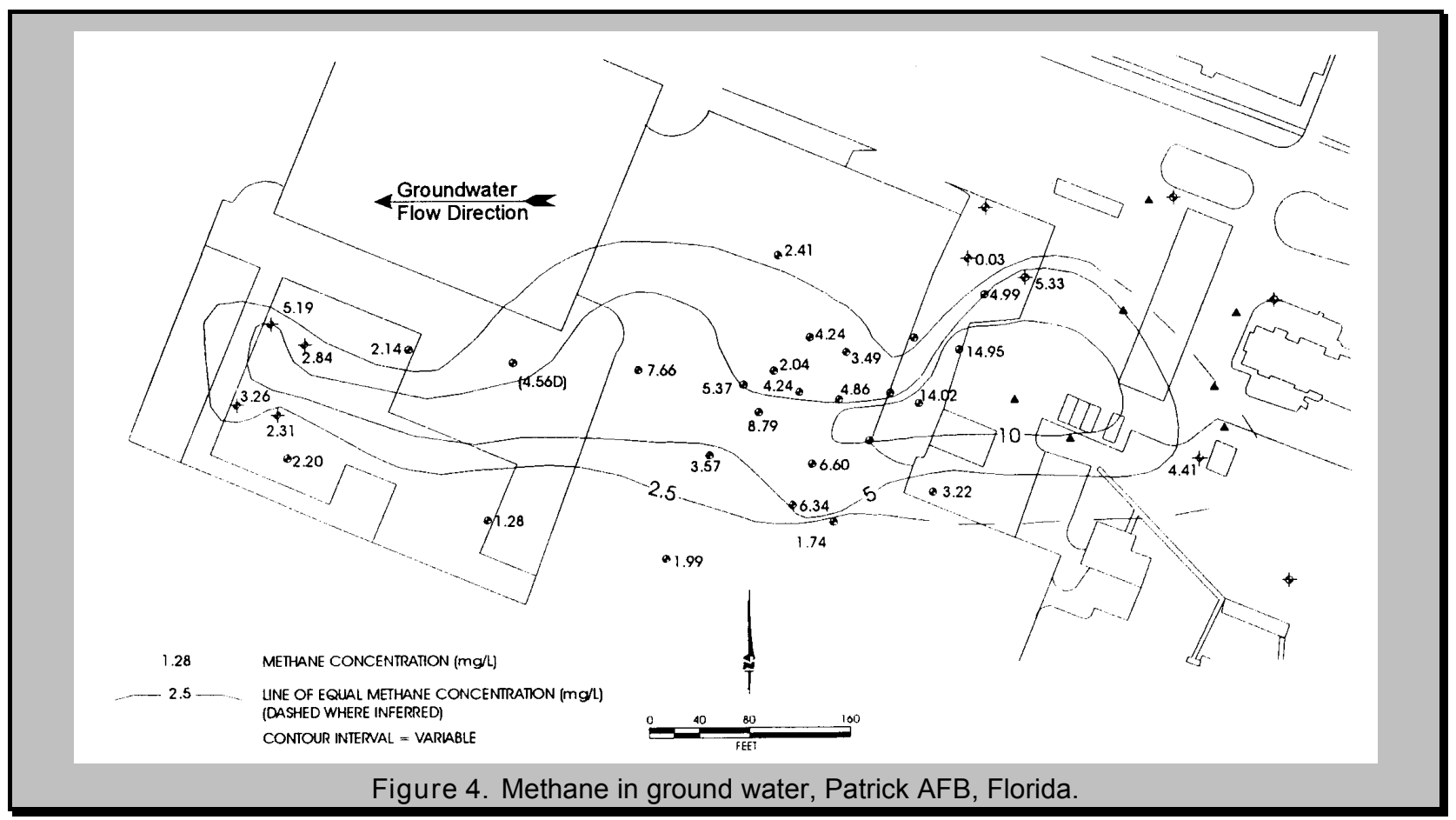

Many of the water samples with depleted dissolved oxygen did contain small amounts of dissolved hydrogen sulfide. The water chemistry suggested that dissolved BTEX would be subjected primarily to aerobic respiration, iron reduction and methanogenesis.

The distribution of dissolved oxygen is shown in Figure 2. Site areas with depleted dissolved oxygen coincided with areas of elevated BTEX, which indicated that aerobic biodegradation was occurring. Background dissolved oxygen was $3.7 \mathrm{mg} / \mathrm{L}$. Based on the Table 1 stoichiometry, there- fore, the shallow ground water had an assimilation capacity of $1200 \mu \mathrm{g} / \mathrm{L}$ total BTEX (Table 5).

Ferrous iron distribution (Figure 3 ) in the site ground water showed a direct relationship with elevated total BTEX. Background of ferrous iron was near $0.1 \mathrm{mg} / \mathrm{L}$ while levels up to $1.9 \mathrm{mg} / \mathrm{L}$ were present in the plume. Based on the Table 1 stoichiometry, the iron reduction would have the capacity to assimilate at least $90 \mu \mathrm{g} / \mathrm{L}$ of the total BTEX. Replenishment of the ferrous iron from soil iron oxides could occur to in-

\begin{tabular}{l|cccc}
\hline \multicolumn{1}{c|}{ Compound } & $\begin{array}{c}\text { Point B } \\
\text { Corrected } \mu \mathrm{g} / \mathrm{L}\end{array}$ & $\begin{array}{c}\text { Biodegradation } \\
\text { A to B \% }\end{array}$ & $\begin{array}{c}\text { Point C } \\
\text { Corrected } \mu \mathrm{g} / \mathrm{L}\end{array}$ & $\begin{array}{c}\text { Biodegradation } \\
\text { B to C \% }\end{array}$ \\
\hline Benzene & 25710 & 0 & 9 & 99 \\
Toluene & 455 & 38 & 19 & 0 \\
Ethylbenzene & 321 & 61 & 19 & 0 \\
Xylenes & 3214 & 36 & 139 & 0 \\
Trimethylbenzene & 750 & 0 & 28 & 0 \\
\hline
\end{tabular}

Table 4. Percent loss using TMB-corrected concentrations. 
crease iron reduction capacity.

Methane distribution is shown in Figure 4. A direct relationship occurred between elevated methane and total BTEX concentrations, which indicated that methanogenesis was occurring. Background methane was near $1 \mathrm{mg} / \mathrm{L}$ while the highest plume methane concentration was $14.6 \mathrm{mg} / \mathrm{L}$. Assimilation capacity during methanogenesis based on stoichiometry would be at least $17,400 \mu \mathrm{g} / \mathrm{L}$ of total BTEX (Table 5). Actual methanogenic assimilative capacity could be much higher because the amount of available carbon dioxide was not included. Methane-corrected BTEX concentrations at points $A, B$ and $C$ also provided evidence that intrinsic bioremediation was occurring (Table 3).

\section{ASSIMILATIVE CAPACITY}

The expressed BTEX assimilative capacity of the site ground water was $18,690 \mu \mathrm{g} / \mathrm{L}$ (Table 5) based on stoichiometry and site geochemical data. Since the highest dissolved BTEX concentration at the site was $7300 \mu \mathrm{g} / \mathrm{L}$, the ground water had sufficient capacity to degrade dissolved BTEX that had partitioned oily residual from the soil into ground water before the plume moved beyond 250 meters downgradient from the source. The remaining assimilative capacity could be consumed by other gasoline components such as aliphatic hydrocarbons.

\begin{tabular}{l|c}
\hline Aerobic respiration & $1200 \mu \mathrm{g} / \mathrm{L}$ \\
Ferric Hydioxide Reduction & 90 \\
Methanogenesis & 17400 \\
Total & 18690 \\
Highest total BTEX & 7300 \\
\hline
\end{tabular}

Table 5. Assimilative capacity of site ground water.

\section{MICROBIAL BREAKDOWN COMPONENTS}

A ground water sample was collected at Point A (Figure 1) for analysis of phenols and aliphatic/aromatic acids. The technique involved liquid-liquid extraction, derivatization, and gas chromatography/mass spectrometry analysis. Major components detected were branched heptanoic and octanoic acids, trimethylbenzonic acids, dimethylbenzonic acids, and some lower molecular weight acids such as propinoic and butyric. The presence of these fatty acid components in the BTEX plume is further evidence that viable microbial biodegradation processes are functional at the site.

\section{RATE CONSTANT}

A first order biological decay rate was calculated using methane as a surrogate tracer. We assumed that once methane was produced from the fuel biodegradation it was stable and, therefore, could be used as a tracer. Table 2 lists methane-corrected BTEX and the amount lost between the A, $B$ and $C$ points. The biodegradation line slope between points $A$ and $C$ approximates a first order process. The average decay rate using retarded solute transport velocity for total BTEX was 0.014 week $^{-1}$. This was within the range reported by Wilson et al. [2].

\section{CONCLUSION}

Three lines of evidence to identify intrinsic bioremediation at the site were loss of contaminants at field scale, geochemical data, and the presence of intermediate microbial BTEX breakdown products. Contaminant loss showed that natural attenuation was occurring. Ground water chemistry determined the relative importance of each operating natural attenuation mechanism. The presence of volatile organic acids showed that microbial biodegradation processes were viable. Aerobic respiration and 
methanogenesis accounted for the greatest mass of BTEX mineralized.

\section{DISCLAIMER}

The research described has not been subjected to the U.S. Environmental Protection Agency's review process. Therefore, an official endorsement should not be inferred.

\section{REFERENCES}

1. T.H. Wiedemeier, D.C. Downey, J.T. Wilson, D.H. Kampbell, R.N. Miller and J.E. Hansen, Technical Protocol for Implementing Intrinsic Remediation with Long-Term Monitoring for Natural Attenuation of Fuel Contamination Dissolved in Groundwater (draft), Air Force Center for Environmental Excellence, Brooks Air Force Base, Texas, 1994.

2. B.H. Wilson, J.T. Wilson, D.H. Kampbell and B.E. Bledsoe, "Traverse City: Geochemistry and Intrinsic Bioremediation of BTX Compounds," In: Proceedings of the Symposium on Intrinsic Bioremediation of Ground Water, U.S. Environmental Protection Agency, 1994, pp 94102. 